Holistik Jurnal Kesehatan, Volume 12, No.4, Oktober 2018: 265-270

\title{
PENGARUH KEJADIAN KECACINGAN TERHADAP KADAR HB DAN INDEKS MASA TUBUH ANAK
}

\author{
Vierto Irennius Girsang ${ }^{1}$, Rismawati Munthe $^{2}$, Teguh Pribadi ${ }^{3}$
}

\author{
1Dosen Universitas Sari Mutiara Indonesia. Email: Iren_ljc@yahoo.com \\ ${ }^{2}$ Dosen Universitas Sari Mutiara Indonesia. \\ ${ }^{3}$ Dosen Program Studi Ilmu Keperawatan, Fakultas Kedokteran Universitas Malahayati Bandar Lampung. \\ Email: teguh@malahayati.ac.id
}

\section{ABSTRACT: HEMOGLOBIN LEVELS AND BODY MASS INDEX WITH THE SOIL-TRANSMITTED HELMINTH INFECTIONS AMONG ELEMENTARY SCHOOL CHILDREN}

Background: Children in tropical countries have more helminth infections which can cause blood loss through the gastrointestinal tract. Helminth infections and micronutrient deficiencies are closely related this can result in a decrease in endurance and cause disruption of child development.

Purpose: This study aims to determine the effect of helminthiasis on hemoglobin levels and body mass index of elementary school children at Silahisabungan District, Dairi Regency, North Sumatra Province.

Methods: This research was an observational analytic cross sectional approach. Subject study as many as 116 children. The study was carried out by examining feces, hemoglobin and counting body mass index the subjects. Statistical analysis used compare means with $95 \% \mathrm{Cl}(\alpha=0,05)$.

Results: In this study, showed that children infected with worms have significant effect on levels of hemoglobin ( $p$ $<0.05)$. The other result there is associated between worm infection with body mass index $(p<0.05)$.

Suggestion: The recommended of this study, important to give regular worm medicine and examination.

Keywords: Helminth, infections, hemoglobin levels, body mass index

Latar Belakang: Anak-anak di negara tropis lebih banyak mengalami infeksi kecacingan yang dapat menyebabkan kehilangan darah melalui saluran cerna. Secara kumulatif infeksi cacinganan dapat menimbulkan kekurangan gizi dan kehilangan darah yang berakibat menurunnya daya tahan tubuh dan menimbulkan gangguan tumbuh kembang anak.

Tujuan: Penelitian ini bertujuan untuk mengetahui pengaruh kejadian kecacingan terhadap kadar $\mathrm{Hb}$ dan indeks masa tubuh anak Sekolah Dasar Kecamatan Silahisabungan Kabupaten Dairi Provinsi Sumatera Utara.

Metode: Penelitian ini merupakan studi observasional dengan rancangan cross sectional. Tahapan penelitian dilakukan dengan pemeriksaan fases siswa untuk mendapatkan anak yang kecacingan dan yang tidak kecacingan. Selanjutnya membandingkan indeks massa tubuh dan kadar hemoglobin pada anak sekolah dasar yang positif kecacingan dan anak yang negatif kecacingan. Besar sampel pada penelitian ini sebanyak 116 siswa. Analisa statistik yang digunakan uji beda mean dengan $95 \% \mathrm{Cl}(a=0,05)$.

Hasil: Diperoleh ada perbedaan rata-rata indeks massa tubuh anak yang kecacingan dan yang tidak kecacingan dengan nilai $p<0,05$. Ada perbedaan rata-rata kadar $\mathrm{Hb}$ pada anak yang kecacingan dan tidak kecacingan dengan nilai $p<0.05$.

Saran: Perlu adanya pemberian obat cacing yang teratur serta pemeriksaan kecacingan yang rutin pada siswa.

Kata kunci: kecacingan, kadar hemoglobin dan indeks massa tubuh 


\section{PENDAHULUAN}

Anak-anak di negara tropis lebih banyak mengalami infeksi kecacingan yang dapat menyebabkan kehilangan darah melalui saluran cerna (Gibney, 2009). Lebih dari 270 juta anak usia pra sekolah tinggal di daerah di mana parasit ini ditularkan secara intensif dan membutuhkan pengobatan serta tindakan pencegahan (James, \& Nyoman, 2012).

Sekitar 40 hingga 60 persen penduduk Indonesia menderita cacingan. dan penderita di kalangan anak sekolah pun masih cukup tinggi. Menurut survei yang pernah dilakukan oleh Sub Direktorat Penanggulangan dan Pencegahan Diare, Cacingan, dan ISPL, Departemen Kesehatan Jakarta di suatu daerah terutama pada anak Sekolah Dasar (SD) menyebutkan sekitar 49,5 persen dari 3160 siswa di 13 SD ternyata menderita cacingan. Siswa perempuan memiliki prevalensi lebih tinggi yaitu 51,5 persen dibandingkan dengan siswa laki-laki yang hanya 48,5 persen (James, \& Nyoman, 2012; Safar, 2010).

Cacingan dapat mengakibatkan menurunnya kondisi kesehatan, gizi, kecerdasan dan produktifitas penderitanya sehingga secara ekonomi banyak menyebabkan kerugian. Cacingan menyebabkan kehilangan karbohidrat dan protein serta kehilangan darah, sehingga menurunkan kualitas sumber daya manusia ( De Gier, Nga, Winichagoon, Dijkhuizen, Khan, Van De Bor, \& Wieringa, 2016; Soerdarto, 2009).

Anak yang terinfeksi kecacingan akan mengalami kekurangan hemoglobin $(\mathrm{Hb})$ hingga 12 gr persen dan akan berdampak terhadap kemampuan darah membawa oksigen ke berbagai jaringan tubuh, termasuk ke otak. Akibatnya, penderita cacingan terserang penurunan daya tahan tubuh serta metabolisme jaringan otak. Bahkan dalam jangka panjang, penderita akan mengalami kelemahan fisik dan intelektualitas. Jika anak-anak sudah terinfeksi cacing, baisanya akan menunjukkan gejala keterlambatan fisik, mental dan seksual (Koes, 2009; Sotelo, 2014).

Cacingan mempengaruhi pemasukan (intake), pencernaan (digestif), penyerapan (absorpsi), dan metabolisme makanan. Secara kumulatif infeksi cacinganan dapat menimbulkan kurangan gizi berupa kalori dan protein, serta kehilangan darah yang berakibat menurunnya daya tahan tubuh dan menimbulkan gangguan tumbuh kembang anak. Khusus anak usia sekolah, keadaan ini akan berakibat buruk pada kemampuannya dalam mengikuti pelajaran di sekolah (De Gier, Nga, Winichagoon, Dijkhuizen, Khan, Van De Bor, \& Wieringa, 2016; Gibney, Barrie, Jhon, \& Lenore, 2009).

Hasil penelitian di Manado pada tahun 2014 oleh Muhammad Fachrurrozy, Basalamah, dkk menunjukkan bahwa anak-anak yang terinfeksi cacing mempunyai hubungan terhadap kadar hemoglobin. Anak-anak yang terinfeksi cacing memiliki kadar hemoglobin lebih rendah bila dibandingkan dengan anak-anak yang tidak terinfeksi cacing (Basalamah, Pateda, \& Rampengan, 2014).

Kadar $\mathrm{Hb}$ dan IMT adalah indikator status gizi anak SD tersebut. Jika kadar $\mathrm{Hb}$ dibawah normal dan IMT dalam kategori kurus dan sangat kurus hal ini akan berdampak pada prestasi anak SD tersebut (De Gier, Nga, Winichagoon, Dijkhuizen, Khan, Van De Bor, \& Wieringa, 2016; Hailu, Yimer, Mulu, \& Abera, 2018).

Menurut peneliti jika anak SD mengalami kecacingan dalam jangka waktu yang lama maka akan mengalami kekurangan gizi kronis. Hipotesis yang akan diuji oleh peneliti adalah bahwa ada pengaruh kecacingan terhadap kadar $\mathrm{Hb}$ darah anak SD dan hipotesis yang kedua adalah bahwa ada pengaruh kecacingan terhadap IMT anak SD. Penelitian ini bertujuan untuk mengetahui pengaruh kejadian kecacingan terhada kadar $\mathrm{Hb}$ dan indeks masa tubuh anak SD di Kecamatan Silahisabungan Kabupaten Dairi Provinsi Sumatera Utara.

\section{METODE PENELITIAN}

Helmint (cacing) adalah salah satu kelompok parasit yang dapat merugikan manusia. Berdasarkan taksonomi, helmint dibagi menjadi dua yaitu Nemathelminthes (cacing gilik) dan Platyhelminthes (cacing pipih). Cacing yang termasuk Nemathelminthes yaitu kelas Nematoda yang terdiri dari Nematode usus dan Nematoda jaringan. Sedangkan yang termasuk Platyhelminthes adalah kelas Trematoda dan Cestoda (Ideham, \& Pusarawati, 2007; Koes, 2009).

Namun yang akan dibahas di bawah ini adalah kelompok Nematoda usus. Sebab sebagian besar dari Nematoda usus ini merupakan penyebab kecacingan yang sering dijumpai pada masyarakat Indonesia khususnya pada usia Sekolah Dasar. Diantara Nematoda usus ini yang

Vierto Irennius Girsang' Dosen Universitas Sari Mutiara Indonesia. Email: Iren ljc@yahoo.com

Rismawati Munthe ${ }^{2}$ Dosen Universitas Sari Mutiara Indonesia.

Teguh Pribadi ${ }^{3}$ Dosen Program Studi llmu Keperawatan, Fakultas Kedokteran Universitas Malahayati Bandar Lampung. Email: teguh@malahayati.ac.id 
sering menginfeksi manusia ditularkan melalui tanah atau disebut "soil transmitted helminths" yakni Ascaris lumbricoides, Trichuris trichiura dan Hookworm (Necator americanus dan Ancylostoma duodenale) (James, \& Nyoman, 2012; Grimes, Tadesse, Gardiner, Yard, Wuletaw, Templeton, \& Drake, 2017).

Didalam epidemiologi deskriptif dipelajari bagaimna frekuensi penyakit berubah menurut perubahan variabel-variabel epidemiologi yang terdiri dari orang (person), tempat (place), dan waktu (time) (Mubarak, \& Chayatin, 2009). Menurut Kementerian Kesehatan (2013), angka kecacingan di Indonesia adalah 28\%. Sedangkan berdasarkan data yang diperoleh di Dinas Kesehatan Provinsi Sumatera Utara, dari 1.358 sampel yang diuji, ditemukan 624 siswa atau 50\% siswa sekolah dasar (SD) positif mengalami penyakit cacingan (Sisca, 2017). Menurut penelitian Zukhriachi (2008) dalam Panggabean pada anak Siswa SD Negeri di Kecamatan Sibolga dari 120 sampel ditemukan 67 orang yang positif kecacingan dengan rincian anak laki-laki 41 orang $(66,1 \%)$ dan anak perempuan 26 orang $(44,8 \%)$ (Sisca, 2017).

$\mathrm{Di}$ Indonesia penyakit infeksi yang disebabkan oleh cacing masih tinggi prevalensinya yaitu $60 \%$ - $80 \%$. Hal ini terjadi dikarenakan Indonesia berada dalam posisi geografis yang temperatur dan kelembaban yang sesuai untuk tempat hidup dan berkembang biaknya cacing. Pengaruh lingkungan global dan semakin meningkatnya komunitas manusia serta kesadaran untuk menciptakan perilaku higiene dan sanitasi yang semakin menurun merupakan faktor yang mempunyai andil yang besar terhadap penularan parasit ini (Taylor, Maayan, Soares, Donegan, \& Garner, 2015; Siwy, Bolang, \& Momongan, 2013).

Penyakit Kecacingan menunjukkan fluktuasi musiman. Biasanya insiden meningkat pada permulaan musim hujan, karena curah hujan sangat erat kaitannya dengan kelembaban tanah tempat telur cacing berkembang biak. Lingkungan tanah liat sangat menguntungkan bagi cacing Ascaris lumbricoides dan Trichuris trichiura sedangkan lingkungan yang mengandung pasir sangat menguntungkan bagi cacing Hookworm (James, \& Nyoman, 2012; Grimes, Tadesse, Gardiner, Yard, Wuletaw, Templeton, \& Drake, 2017).

Penelitian ini merupakan observasional dengan menggunakan rancangan cross sectional. Tahapan penelitian dilakukan dengan membandingkan indeks massa tubuh dan kadar hemoglobin pada anak sekolah dasar. Analisis univariat digunakan untuk menjelaskan deskripsi karakteristik masing-masing variabel. Penyajian data dilakukan dalam bentuk tabel distribusi frekuensi. Dalam analisis bivariat analisis statistik yang digunakan adalah uji beda mean untuk mengetahui beda mean kadar $\mathrm{Hb}$ dan IMT anak SD yang mengalami kecacingan. Uji statistik yang digunakan adalah uji beda rata-rata, jika data tidak terdistribusi normal maka data tersebut akan dilakukan pernormalan data.

\section{HASIL PENELITIAN}

Lokasi penelitian ini dilakukan di lima SD di Kecamatan Silahisabungan Kabupaten Dairi Provinsi Sumatera Utara. Penelitian ini dilaksanakan bulan Agustus 2018 dengan besar sampel pada penelitian ini sebanyak 116 siswa SD.

Table 1

Distribusi Kejadian kecacingan Dengan Indeks Massa Tubuh Pada Anak Sekolah Dasar di Kecamatan Silahisabungan Tahun 2018.

\begin{tabular}{|c|c|c|c|c|c|}
\hline Kecacingan & Jumlah & Rata-rata IMT & SD & SE & $p$-value \\
\hline $\begin{array}{c}\text { Terinfeksi } \\
\text { Tidak Terinfeksi }\end{array}$ & $\begin{array}{l}32 \\
84\end{array}$ & $\begin{array}{l}17,1 \\
16.1\end{array}$ & $\begin{array}{l}2,6 \\
2,2\end{array}$ & $\begin{array}{l}0,45 \\
0,24\end{array}$ & 0,0001 \\
\hline
\end{tabular}

Pada table 1. rata-rata indeks massa tubuh anak yang kecacingan adalah 17,1 dengan standart deviasi 2,6. Sedangkan untuk anak yang tidak kecacingan rata-rata indeks massa tubuh anak adalah 16,1 dengan

Vierto Irennius Girsang' Dosen Universitas Sari Mutiara Indonesia. Email: Iren ljc@yahoo.com Rismawati Munthe ${ }^{2}$ Dosen Universitas Sari Mutiara Indonesia.

Teguh Pribadi ${ }^{3}$ Dosen Program Studi llmu Keperawatan, Fakultas Kedokteran Universitas Malahayati Bandar Lampung. Email: teguh@malahayati.ac.id 
standart deviasi 2,2. Hasil uji statistik didapatkan nilai $p=0,001$, yang berarti pada alpha $5 \%$ terlihat ada perbedaan yang signifikan rata-rata indeks massa tubuh antara anak yang kecacingan dan tidak kecacingan.

Table 2

Distribusi Kejadian kecacingan Dengan Hemoglobin Pada Anak Sekolah Dasar di Kecamatan Silahisabungan Tahun 2018.

\begin{tabular}{cccccc}
\hline Kecacingan & Jumlah & Rata-Rata Hb & SD & SE & p-value \\
\hline Terinfeksi & 32 & 9,4 & 0,8 & 0,15 & \multirow{2}{*}{0,0001} \\
Tidak & 84 & 11,5 & 1,9 & 0,2 & \\
Terinfeksi & & & & & \\
\hline
\end{tabular}

Berdasarkan tabel 2 rata-rata kadar hemoglobin anak yang kecacingan adalah 9,4 dengan standart deviasi 0,8 . Sedangkan untuk anak yang tidak kecacingan rata-rata kadar hemoglobin anak adalah 11,5 dengan standart deviasi 1,9. Hasil uji statistik didapatkan nilai $p=0,001$, yang berarti pada alpha $5 \%$ terlihat ada perbedaan yang signifikan rata-rata kadar hemoglobin antara anak yang kecacingan dan tidak kecacingan.

\section{PEMBAHASAN}

Kekurangan gizi berhubungan dengan infeksi parasit salah satunya adalah infeksi cacing pada populasi endemik. Tingginya prevalensi infeksi kecacingan pada anak usia 6 - 19 tahun berhubungan dengan stunting, wasting dan underweight (Silva, 2017; Samudar, Hadju, \& Jafar, 2013). Infeksi Ascaris Lumbricoides dan hookworm berkaitan dengan status gizi. Infeksi Ascaris lumbricoides 10.000 epg meningkatkan stunting pada anak dan dewasa. Infeksi ascariasis dan trichuriasis tingkat sedang maupun berat berhubungan dengan stunting. Infeksi Ascaris Lumbricoides dan hookworm signifikan berefek buruk pada penurunan berat badan bagi yang terinfeksi dibandingkan dengan yang tidak terinfeksi. Pengaruh beratnya infeksi Ascaris Lumbricoides dan hookworm berefek pada pertumbuhan dan proses perkembangan anak. Infeksi parasit usus berat pada trichuriasis merupakan predictor stunting dan wasting pada usia 2-6 tahun (Gibney, 2009).

Hasil penelitian ini menunjukkan rata-rata indeks massa tubuh anak yang kecacingan adalah 17,1 dengan standart deviasi 2,6. Sedangkan untuk anak yang tidak kecacingan rata-rata indeks massa tubuh anak adalah 16,1 dengan standart deviasi 2,2. Hasil uji statistik didapatkan nilai $p=0,001$, yang berarti pada alpha $5 \%$ terlihat ada perbedaan yang signifikan rata-rata indeks massa tubuh antara anak yang kecacingan dan tidak kecacingan.

Intensitas infeksi sedang sampai berat serta infeksi lebih dari satu cacing merupakan prediktor penurunan berat badan pada anak-anak usia 7-10 tahun. Infestasi cacing pada usus akan menimbulkan keseimbangan nitrogen negatif yang apabila timbul dalam keadaan yang terus menerus akan mengakibatkan malnutrisi sehingga dapat menyebabkan gangguan pertumbuhan. Keadaan ini terjadi apabila asupan makanan tidak mencukupi bagi parasit dan hospes (Gier et al. 2016; Sotelo 2014).

Penelitian ini berbeda dengan hasil penelitian Panggabean (2017) menyatakan tidak ada hubungan kejadian kecacingan dengan status gizi (IMT/U) pada anak sekolah dasar di kecamatan Silahisabungan Kabupaten Dairi tahun 2017. Dimana anak yang status gizi sangat kurus memiliki nilai $P$ value 0,063 , anak yang status gizi kurus memiliki nilai $P$ value 1,000 dan anak yang status gizi normal memiliki nilai $P$ value 0.090 (Sisca, 2017).

Penelitian ini sejalan dengan penelitian yang mengatakan bahwa ada hubungan yang bermakna antara infeksi kecacingan dengan status gizi berdasarkan $\mathrm{BB} / \mathrm{U}$ dan $\mathrm{TB} / \mathrm{U}$. Penelitian lain yang juga sama dengan penelitian ini adalah penelitian mengatakan bahwa ada hubungan yang bermakna antara infeksi kecacingan dengan status gizi. Perbedaan budaya, kebiasaan, dan pengetahuan tentang gizi juga membuat hasil penelitian ini berbeda (De Gier, Nga, Winichagoon, Dijkhuizen, Khan, Van De Bor, \& Wieringa, 2016; Siwy, Bolang, \& Momongan, 2013).

Infeksi cacing berpengaruh terhadap pemasukan, pencernaan, penyerapan, serta metabolisme makanan yang dapat berakibat hilangnya protein, karbohidrat, lemak, vitamin dan darah dalam jumlah yang besar, juga menimbulkan gangguan respon imun,

Vierto Irennius Girsang' Dosen Universitas Sari Mutiara Indonesia. Email: Iren ljc@yahoo.com

Rismawati Munthe ${ }^{2}$ Dosen Universitas Sari Mutiara Indonesia.

Teguh Pribadi ${ }^{3}$ Dosen Program Studi llmu Keperawatan, Fakultas Kedokteran Universitas Malahayati Bandar Lampung. Email: teguh@malahayati.ac.id 
menurunnya plasma insulin like growth factor (IGF)-1, meningkatkan kadar serum tumor necrosis factora (TNF) dan menurunkan konsentrasi hemoglobin. Di samping itu dapat menimbulkan berbagai gejala penyakit seperti anemia (Silva, 2017; Grimes, Tadesse, Gardiner, Yard, Wuletaw, Templeton, \& Drake, 2017).

Hasil penelitian ini menunjukkan rata-rata kadar hemoglobin anak yang kecacingan adalah 9,4 dengan standart deviasi 0,8. Sedangkan untuk anak yang tidak kecacingan rata-rata kadar hemoglobin anak adalah 11,5 dengan standart deviasi 1,9. Hasil uji statistik didapatkan nilai $p=0,001$, yang berarti pada alpha $5 \%$ terlihat ada perbedaan yang signifikan rata-rata kadar hemoglobin antara anak yang kecacingan dan tidak kecacingan.

Hasil penelitian ini sama dengan penelitian Panggabean tahun 2017 menunjukkan bahwa ada perbedaan rata-rata kadar hemoglobin pada anak yang positif kecacingan dan negatif kecacingan. Dimana rata-rata kadar $\mathrm{Hb}$ pada anak yang positif kecacingan adalah 9,723 gr/dl dengan standart deviasi 1,0634 gr/dl, sedangkan untuk anak yang negatif kecacingan rata-rata kadar hemoglobinnya adalah 12,192 gr/dl dengan standart deviasi $1,1801 \mathrm{gr} / \mathrm{dl}$. Hasil uji statistic didapatkan nilai $p=0,000$, dengan $t=-9.695$, berarti pada $a=0.05$ terlihat ada perbedaan yang signifikan rata-rata kadar hemoglobin antara anak yang positif kecacingan dan negatif kecacingan (Sisca, 2017).

Di indonesia, sekitar $60 \%$ orang mengalami infeksi cacing. Kelompok umur terbanyak adalah usia anak sekolah dasar yaitu 5-14 tahun. Dari segi kesehatan anak yang terinfeksi cacing terindikasi lesu, lemah, konjungtiva anemis, dan penurunan nafsu makan, karena cacing menyerap nutrisi dari tubuh anak dan pada gilirannya anak akan mengalami defisiensi yang bisa menyebabkan kadar hemoglobin menjadi rendah atau tidak normal(Mubarak 2009; Utara and Mayulu 2013). Hal ini sesuai dengan penelitian yang menunjukkan bahwa anak-anak yang terinfeksi cacing mempunyai hubungan terhadap kadar haemoglobin. penelitian ini juga sejalan dengan penelitian yang menyatakan ada hubungan antara infeksi kecacingan dengan kadar haemoglobin dengan (Samudar, Hadju, \& Jafar, 2013).

\section{SIMPULAN}

Berdasarkan hasil penelitian maka dapat ditarik kesimpulan sebagai ada hubungan yang signifikan kejadian kecacingan dengan indeks massa tubuh pada anak sekolah dasar di Kecamatan Silahisabungan. Ada hubungan yang signifikan kejadian kecacingan dengan kadar haemoglobin pada anak sekolah dasar di Kecamatan Silahisabungan.

\section{SARAN}

Bagi Puskesmas agar memberikan obat cacing secara rutin dua kali dalam satu tahun dan melakukan pemeriksaan kecacingan secara rutin pada anak Sekolah Dasar.

\section{UCAPAN TERIMA KASIH}

Ucapan terima Kasih saya sampaikan kepada Direktorat Riset dan Pengabdian kepada Masyarakat, Jenderal Penguatan Riset dan Pengembangan Kementerian Riset, Teknologi dan Pendidikan Tinggi Republik Indonesia yang telah mendanai penelitian ini.

\section{DAFTAR PUSTAKA}

Basalamah, M. F., Pateda, V., \& Rampengan, N. (2014). Hubungan Infeksi Soil Transmitted Helminth Dengan Kadar Hemobglobin Anak Sekolah Dasar Gmim Buha Manado. eClinic, 2(1).

De Gier, B., Nga, T. T., Winichagoon, P., Dijkhuizen, M. A., Khan, N. C., Van De Bor, M., ... \& Wieringa, F. T. (2016). Species-specific associations between soil-transmitted helminths and micronutrients in Vietnamese schoolchildren. The American journal of tropical medicine and hygiene, 95(1), 77-82.

Gibney, M. J. (2009). Gizi kesehatan masyarakat. EGC.

Grimes, J. E., Tadesse, G., Gardiner, I. A., Yard, E., Wuletaw, Y., Templeton, M. R., ... \& Drake, L. J. (2017). Sanitation, hookworm, anemia, stunting, and wasting in primary school children in southern Ethiopia: Baseline results from a study in 30 schools. PLoS neglected tropical diseases, 11(10), e0005948.

Hailu, T., Yimer, M., Mulu, W., \& Abera, B. (2018). Synergetic Effects of Plasmodium, Hookworm, and Schistosoma mansoni Infections on Hemoglobin Level among Febrile School Age Children in Jawe Worda, Northwest Ethiopia. Journal of Parasitology Research, 2018.

\footnotetext{
Vierto Irennius Girsang' Dosen Universitas Sari Mutiara Indonesia. Email: Iren ljc@yahoo.com Rismawati Munthe ${ }^{2}$ Dosen Universitas Sari Mutiara Indonesia.

Teguh Pribadi ${ }^{3}$ Dosen Program Studi llmu Keperawatan, Fakultas Kedokteran Universitas Malahayati Bandar Lampung. Email: teguh@malahayati.ac.id
} 
Ideham, B., \& Pusarawati, S. (2007). Helmintologi Kedokteran.

James, C., \& Nyoman, K. (2012). Manual Pemberantasan Penyakit Menular. Infomedika Edisi, 17.

Koes, I. (2009). Parasitologi: berbagai penyakit yang mempengaruhi kesehatan manusia. Bandung: CV Yrama Widya.

Mubarak, W. I., \& Chayatin, N. (2009). IImu kesehatan masyarakat: teori dan aplikasi. Jakarta: Salemba Medika, 393.

Silva, R. D. C. R. (2017). Effectiveness of the treatment of helminth infections (S. mansoni, Ancylostomidae, T. trichiura, A. lumbricoides) on hemoglobin concentration in school-children and adolescents.

Samudar, N., Hadju, N., \& Jafar, N. (2013). Hubungan infeksi kecacingan dengan status hemoglobin pada anak sekolah dasar di wilayah pesisir Kota Makassar Propinsi Sulawesi Selatan 2013 [internet]. 2013 [cited 2015 December 1]

Safar, R. (2010). Parasitologi Kedokteran: protozoologi, entomologi, dan helmintologi. Bandung: Yrama Widya.
Sisca, P. 2017. "Hubungan Kejadian Kecacingan Dengan Indeks Massa Tubuh, Kadar Hemoglobin Dan Prestasi Belajar Pada Anak Sekolah Dasar Di Desa Silahi Sabungan Tahun 2017." Prodi Kesehatan Masyarakat Universitas Sari Mutiara Indonesia.

Siwy, J. L., Bolang, A. S., \& Momongan, N. (2013). Hubungan antara kecacingan dengan status gizi pada siswa kelas 4 dan 5 sd katolik st. Theresia malalayang kota manado relationship worm infection with nutritional status in grade 4 and 5 elementary schools st. Theresia malalayang manado city.

Soedarto. (2009). Pengobatan Penyakit Parasit. Jakarta. CV Sagung Seto.

Sotelo, J. (2014). A Cross-Sectional Study of CoInfection with Helminths and Malaria: The Effect on Hemoglobin Levels among Luo Children in Rural Western Kenya (Doctoral dissertation).

Taylor-Robinson, D. C., Maayan, N., SoaresWeiser, K., Donegan, S., \& Garner, P. (2015). Deworming drugs for soiltransmitted intestinal worms in children: effects on nutritional indicators, haemoglobin, and school performance. Cochrane Database of Systematic Reviews, (7). 